\title{
Digital Media in ESP Instruction for Marketing Communication
}

\section{Digitální média ve výuce angličtiny pro specifické účely zaměřené na marketingovou komunikaci}

\author{
Štěpánka Hronová, Ladislava Knihová
}

\begin{abstract}
Digital media have profoundly changed our lifestyles especially in ways we communicate and consume information while video-on-demand and other video formats are taking the lead. As a result, also students' preferences related to the content and formats of study materials are changing in a dramatic way. Almost every day, not only foreign language teachers can observe how incredibly quickly technologies used in instruction are changing and their own teaching materials are becoming obsolete after significantly shorter time periods compared to the situation several years ago. The aim of this paper is to examine and critically evaluate the existing opportunities for English teachers to incorporate video formats into their portfolio of teaching methods as well as use them effectively in the process of updating their own teaching materials. Due to the fact that creative ideas for methodological application of video formats are fully transferable into almost any kind of study programmes, the paper is complemented by a lesson plan based on the Bring your own device (BYOD) approach and the use of the mobile app iMovie. Further, within the frame of microlearning, the article presents a way of using off-the-shelf videos with technical content as part of interactive presentations prepared and presented by students in ESP classes and also in other specialized subjects. Selected results of the empirical research into the managerial attitudes towards incorporating video formats into corporate training enhance the importance of acquiring innovative skills in the context of foreign language learning already during university studies.
\end{abstract}

Key words: English for specific purposes, off-the-shelf video, digital media, creative use of video, mobile apps, video format, video-on-demand.

\begin{abstract}
Abstrakt: Digitální média zásadně změnila náš životní styl, zejména pak způsob, jakým komunikujeme a konzumujeme informace, přičemž video na vyžádání a další video formáty hrají velmi důležitou roli. $\mathrm{V}$ důsledku toho se dramaticky mění i preference studentů týkající se obsahu a formátu studijních materiálů. Téměř každý den mohou nejen učitelé cizích jazyků pozorovat, jak se neuvěřitelně rychle mění technologie používané ve výuce a jak jejich vlastní studijní materiály zastarávají, a to výrazně rychleji ve srovnání se situací před několika lety. Cílem tohoto příspěvku je prozkoumat a kriticky zhodnotit existující možnosti pro učitele angličtiny, jak začlenit video formáty do svého portfolia výukových metod a jak je efektivně využít v procesu aktualizace vlastních výukových materiálů. Jelikož jsou kreativní nápady pro metodickou aplikaci video formátů plně přenositelné do téměř jakéhokoliv studijního programu, je př́spěvek doplněn plánem hodiny založeným na využití vlastního zařízení studenta (BYOD Bring Your Own Device) a mobilní aplikace iMovie. V rámci tzv. mikroučení (microlearning) článek dále představuje způsob využití existujících videí s odborným obsahem jako součásti interaktivních prezentací připravených a prezentovaných studenty, a to jak v hodinách anglického odborného jazyka, tak i v dalších odborných předmětech. Vybrané výsledky empirického
\end{abstract}


výzkumu manažerských postojů k začlenění video formátů do firemního vzdělávání zvyšují důležitost získání inovativních dovedností v kontextu výuky cizího jazyka již během univerzitního studia.

Klíčová slova: angličtina pro specifické účely, běžně dostupné video, digitální media, kreativní využití videa, mobilní aplikace, video formát, video na vyžádání.

\section{Introduction}

Technological advancement and digital media have significantly changed people's lifestyles and the ways they communicate and consume information. Video-ondemand and other video formats are definitely taking the lead. As a result, students' preferences related to the content and formats of study materials are changing in a dramatic way, too. Almost every day the ESP teachers can observe how incredibly quickly technologies used in foreign language instruction as well as learning materials are becoming obsolete after significantly shorter time periods compared to the situation several years ago. Therefore, a high level of technological expertise and creativity is needed for instant modification and updating of materials used in English for specific purposes teaching. The study programme of marketing communications is a clear evidence of these trends.

The aim of this paper is to examine and critically evaluate the opportunities for ESP teachers to incorporate video formats into the portfolio of their teaching methods as well as use them as a state-of-the-art tool in the inevitable process of updating the study materials for their students. Being an important part of Business and Management study programmes, English language instruction for Marketing Communication students serves as a perfect example of a typical tertiary ESP teaching environment. In addition, creative ideas for methodological application of video are fully transferable into almost any kind of study programmes. Thus, the paper is complemented by examples of good practice in incorporating open-access videos and by a lesson plan with the Bring your own device (BYOD) approach where students themselves become marketing message creators with the use of the mobile app iMovie after having studied several learning nuggets of marketing communication theory.

\section{Theoretical Background and Literature Review}

In this paper, the authors are mainly concerned with video learning as a powerful instructional tool generally and video and other digital media in ESP instruction for Marketing Communication specifically.

In view of the new strategy of the Czech government, adopted in 2019 under the title of Innovation Strategy of the Czech Republic 2019-2030: The Country for the Future (RVVI, 2019) and due to significant governmental support for innova- 
tive industries, the growing emphasis on English for specific purposes represents a new challenge for tertiary education. High expectations are also on the side of corporations, businesses and entrepreneurs. In this context, video learning with authentic English language represents an instructional tool of utmost importance.

A recent research (TrainingZone, 2019) carried out by TrainingZone, a key UK specialist providing guidance, opinions and up-to-date information on Learning \& Development (L\&D) and trends that make a real difference to the modern workplace, has brought some insight into current training practice of 316 organizations. In this global survey carried out among learning and development professionals across EMEA, North America and Asia-Pacific, the TrainingZone's L\&D tech barometer explored the different ways in which organisations view the role of new L\&D technologies and the pace in which new tools are currently being implemented into their training. As for the structure of respondents, organisations of all sizes, from small businesses of 10-49 employees (26\%) up to large-scale enterprises (21\%), were represented. Among the research questions dealing with what technologies are trending in 2019, interesting facts were published on video learning in organizations - see Fig. 1.

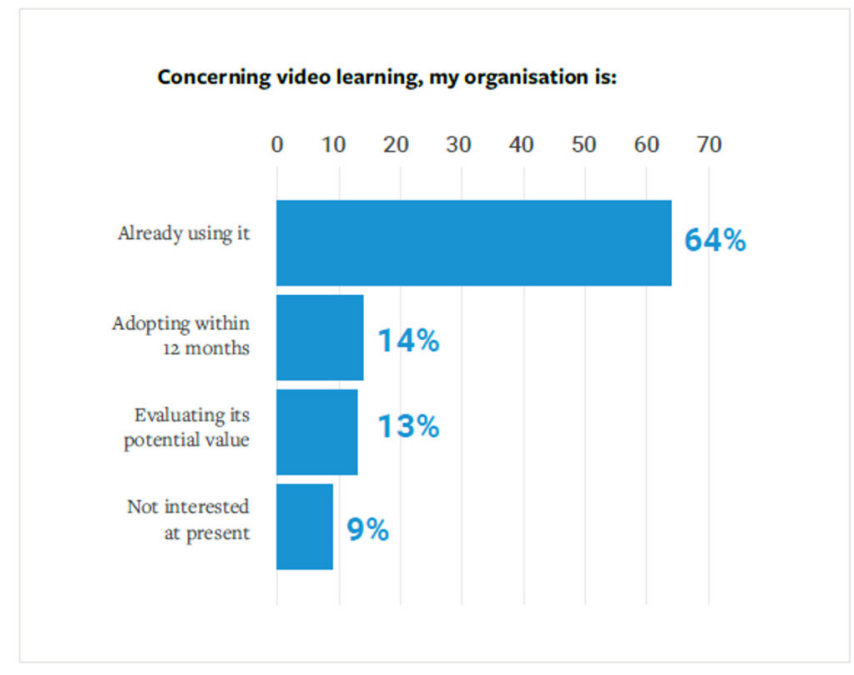

Fig. 1: What technologies are trending in 2019/video learning? Source: TrainingZone 2019

In their interpretation, the authors of the research offer the below quoted explanation and comments. These global findings can be compared to the situation in the corporate training in the Czech Republic (see Chapter 4). 
Given that on YouTube over a billion learning-related videos are viewed every day, and that Ted Talks surpassed their one billionth view back in 2012, it's perhaps not surprising that out of the 10 learning technologies we questioned participants on, video comes out on top, being used by the highest number of respondents (64\%) as a learning tool for employees. Even among slow adopters, $44 \%$ are already using video learning. Another indicator that video is the most popular learning tool among L\&D practitioners currently is that there are only a small number (9\%) who are not interested in video right now. (TrainingZone, 2019, p. 8)

Video and multimedia teaching and learning have been in the focus of attention of many educators. However, not just technology but namely teacher preparation is one of key issues in this debate. In his recent work Multimedia Learning Theory, Patrick Jenlink focused on opportunities that multimedia offers in creating vibrant learning environments.

Changing the focus of teaching and learning to a multimedia-based, learner-centered approach will require that universities change teacher preparation programs and instructional practices to integrate multimedia and digital technologies and multimedia learning theory into the epistemological and pedagogical architecture of educator preparation. Multimedia learning brings to the foreground an integrated, interactive, multisensory approach to preparation and practice that more clearly aligns with the new millennium generation of student entering the school and university classroom. (Jenlink, 2019, p. 5)

In their work A Brief History of the Future of Education Ian Jukes and Ryan L. Schaaf predicted that "learning will be focused on processing multimedia information". (Jukes \& Schaaf 2019, p. 96). The authors believe that both learners and teachers alike need to understand modern information-communication skills, including fundamentals of video production. (Jukes \& Schaaf 2019, p. 96) At the same time, they highlighted the prediction that "learning will be collaborative" and they are sure that "the need for collaboration skills has increased considerably in the hyperconnected modern world" and they explain that 21st century workers will have to master a wide range of new technical skills to be able to operate effectively in virtual teams. (Jukes \& Schaaf 2019, pp. 98-99) Video and multimedia are an important part of these skills.

There is a great number of topics related to the use of video in teaching and video learning, including mobile video learning which is becoming more and more popular. Dealing with all of them is definitely beyond the scope of this paper, however, in connection with video as a tool of learning and source of educational content, at least the following new trends are worth mentioning: (1) video and storytelling, (2) explainer videos, (3) video as an infographic tool, (4) interactive videos and (5) video as a social learning tool. It is highly recommended to follow these new trends with the objective to give our learners an opportunity to experience highquality video-based learning which is visually striking, engaging and memorable.

Last but not least, it is important to consider the use of multimedia in formal learning as a vital skill for future employability of our graduates. If they master 
the necessary digital skills already during their studies, they will be more competent to perform the tasks they will be assigned in their jobs. Paul Matthews, quoting The World Economic Forum's Global Competitiveness Report, highlights: "Skills have a vital role to play to enhance business success. The benefits associated with a higher skilled workforce include improved productivity, better returns, increased employee satisfaction and lower rates of absence and staff turnover". (Matthews 2014, p. 12)

To put it in a wider context, the authors of this treatise are fully convinced about the irreplaceable role of university educators in the preparation of highly skilled future workforce. Since companies and organizations are on their journey towards 'becoming digital', it is the role of educators to provide guidance for today's learners and tomorrow's employees as "a company's short- and long-term survival depends upon the capability of employees - on their existing knowledge, skills and performance and, more importantly, on their ability to keep learning and thus keep expanding their capability to cope with change". (Matthews 2013, p. 20) Teaching English for specific purposes with the use of multimedia is in the core of future success of companies and organizations as well as their employees.

\section{ESP Instruction for Marketing Communication}

Educators are fully aware that they teach students who prefer different learning styles, and they know that a balanced mix of various learning activities is a way to help students learn better. However, at the same time, transforming the learning environment and enriching it with a variety of new learning methods, which are made possible by technological advances, entails a number of pitfalls. By way of illustration, it is advisable to mention at least one example that deals with the issue of including multimedia (multimedia presentations, audio, video, etc.) into the portfolio of teaching methods. This research was devoted to a more thorough understanding of the multimedia function in the learning environment. (SEG Research, 2008) There are selected findings from this research related to our analysis. In the section Brain Processing and Multimedia Learning, the authors ask the following question:

"So, what do we know about brain processing that is relevant to multimedia learning? We know that:

- Effective multimedia recognizes that working memory has a limited capacity to process information.

- Effective multimedia presentations take advantage of both the auditory and visual channels in working memory to deliver content. Using multiple channels increases the overall amount of information the brain can process.

- Effective multimedia understands that text may be particularly challenging to process, with involvement from both the visual and auditory channels required.

- Effective multimedia presentations recognize that long-term memory organizes information into meaningful chunks called schema. Presenting information in a way that makes use of existing organiz- 
ing structures (schema) or that helps students organize the information can greatly assist the learner in incorporating information into Long Term memory." (SEG research 2008, p. 4)

The above-mentioned facts and other useful information from this research can help educators to incorporate multimedia content into their own teaching. Really well-prepared multimedia teaching is based on understanding how the human brain works, and educators can turn this knowledge into a great advantage. (Knihová \& Hronová, 2015)

The ESP instruction for students of Marketing Communications has been in the focus of attention of the Language Department at The University of Finance and Administration for almost a decade. English language classes are evenly spread over six semesters of the bachelor's study programme and four semesters of the master's study programme. Each semester, in addition to other business topics and grammar structures, students study four topics related to marketing communication while their sequence corresponds to other marketing subjects they study in Czech in the particular term. Thus, better comprehension of technical terms and marketing concepts is guaranteed. However, there are challenges we have to deal with due to the fact that marketing is an extremely dynamic discipline. On the top of that, it has become rather technological (readers might be familiar with terms like Facebook Business Manager, Google Analytics, Google Ads, Google Ad Grants, and Instagram Stories etc.). All these new platforms and concepts used in marketing require incorporation and proper understanding of new professional vocabulary and at least rudimentary orientation in the functioning of these platforms and opportunities they offer.

In view of these developments, ESP teachers are partly becoming subject matter experts as well. They have to follow new trends in marketing and modify the learning materials for students continuously.

One of the methodological approaches incorporated into the study programme is 'microlearning in the form of interactive presentations' prepared and presented by students in ESP classes with the frequent use of video (educational video, video animations, how-to videos, video with motion graphs) - see Chapter 5. Topics related to marketing communication involve marketing mix, market environment analyses, marketing strategies, marketing planning, legal aspects of marketing, branding, marketing research, pricing strategies, sales promotion, blogging, etc. On the course of the last two academic years, we have been working with the mobile app iMovie within the Bring your own device (BYOD) approach. This mobile app for video editing is free and students have it mostly pre-installed on their smartphones, or they can easily download it from Apple Store or Google Play. Students usually work on a marketing-related task in small groups and they prepare e.g. a short video promotion focused on product promotion or brand building. They 
should demonstrate not only their knowledge of marketing concepts but they have to acquire/demonstrate the ability to work with visuals, video editing features, inserting the right type of fonts for the marketing message or selecting appropriate background music. Peer-to-peer evaluation of the students' videos is a part of this scenario. A sample lesson plan complements this paper - see Chapter 5.

Incorporation of video formats both into students' PowerPoint presentations and the hands-on experience in creating their own promotional marketing videos are important tools in ESP instruction. They help to create more immersive learning environment and even less tech-savvy students have the opportunity to learn new digital skills from their peers in a group work which is undoubtedly less stressful for them. Ian Jukes and Ryan L. Schaaf believe that

Learners today are vastly different from previous generations [...] Digital learners prefer processing pictures, sounds, color, and video before they process text. [...] Digital learners prefer learning that is simultaneously relevant, active, instantly useful, and fun. (Jukes \& Schaaf, 2019, p. 63)

Before we start implementing video into ESP instruction, it is advisable to take into account contingent barriers. Based on their research, Cédric Sarré et al. commented on the biggest obstacles as follows:

The biggest obstacles for implementing of audio-visual resources (AVR) seemed to be the shortage of time to use video material, the inadequacy of the equipment used, or insufficient computer literacy of teachers who needed to cope with technical problems that occurred in class. (Sarre, 2017, p. 18)

The authors of this paper believe that the above-mentioned barriers can be removed by higher investment into technology (e.g. high-speed Internet) and teacher training. Other barriers, e.g. financial and social barriers, to incorporating video into ESP instruction, are low and there is no reason to leave these beneficious learning opportunities unused and neglect opportunities for their implementation.

\section{Methodology}

In harmony with the research objectives, mixed methods research design has been opted for. It included the following research methods: descriptive analysis, exploratory analysis, online survey, empirical observation, data interpretation and statistical analysis of selected data.

The paper presents two major sets of data based on the empirical research; first of qualitative and second of quantitative character which are described later in this treatise. 
The authors are fully convinced that a well-structured combination of qualitative and quantitative analyses can guarantee a more comprehensive approach with the aim to answer research questions in a more complex way.

\subsection{Empirical research description}

In harmony with the research objectives, mixed methods research design has been opted for. The qualitative research is based on the descriptive analysis. It brings the results of good practice identified and verified by the authors in their tertiary ESP classes as innovative yet quite approachable methods used in foreign language instruction. The paper aims to share good practice of video integration into an ESP classroom. In particular, it shows (a) how existing videos with corresponding educational content can be utilized as a part of interactive PowerPoint presentations in peer-to-peer environment as microlearning units during an ESP class and (b) how students with the help of their own devices (BYOD method) access the mobile app iMovie and create valuable professional video content after having studied a corresponding part of marketing communication theory (Chapter 5).

In harmony with the tertiary educational institution objectives to prepare their graduates in the best possible way for the challenges of practice, the quantitative research introduces a set of research findings on the topic of the open-source videos use in corporate education. When processing the quantitative data, the authors worked with the program for statistical data analysis IBM SPSS version 19. Remote access to the program was enabled by the IT staff at the VSFS where the authors work as Assistant Professors. The following functions have been used: frequency analysis, binomial test, chi-square test for independence of nominal variables. An online survey was conducted among 100 Czech companies in May and June 2019; the online questionnaire consisted of substantial multiple-choice questions ( 3 or 4 options each).

\subsection{Quantitative research results and interpretation}

As there is a strong need for interconnectedness between tertiary education and business practice, the authors strived to examine the practical aspects of training methods with a focus on open source video formats in Czech companies. Three research questions were formulated and the results and their interpretation are presented below.

\section{Research question 1 (RQ1)}

The authors first examined whether companies take into account variety of instructional methods in corporate education as it is fairly common in university 
practice. The research question 1 (RQ1) was as follows: When designing corporate training, a mix of various educational methods and materials is used. The collected data processed by IBM SPSS can be seen in Chart 1 below.

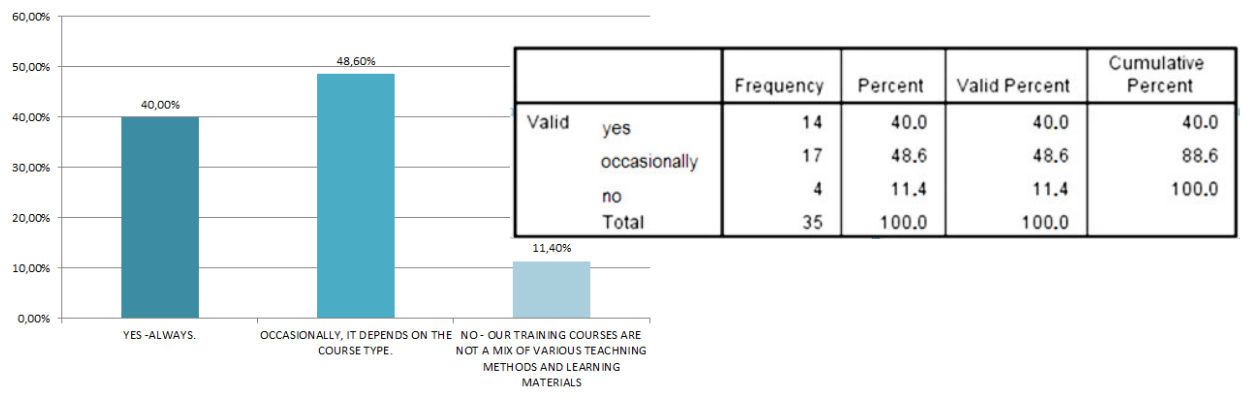

Fig. 2: Results for RQ1 in IBM SPSS

RQ1 interpretation: The research discovered that about half of the companies $(48.6 \%)$ occasionally takes into account various educational activities and methods when designing a corporate course. About $11 \%$ never considers this factor while compiling and designing a course, yet $40 \%$ always puts emphasis on a variety of study materials and methods of instruction.

\section{Research question 2 (RQ2)}

Further, the authors were interested in the utilization of freely accessible video formats with valuable and high-quality content and their use among instructional design methods of corporate education. Thus, research question 2 (RQ2) was formulated as follows: In our corporate training, we use high quality open access educational videos. Results are presented in Chart 2 and the interpretation can be seen below.

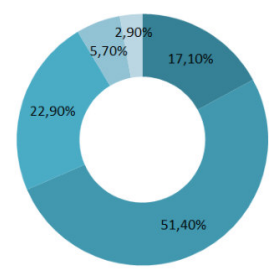

\begin{tabular}{|c|c|c|c|c|c|c|}
\hline \multirow{2}{*}{$=$ YES - ALWAYS } & & & Frequency & Percent & Valid Percent & $\begin{array}{c}\text { Cumulative } \\
\text { Percent }\end{array}$ \\
\hline & \multirow[t]{5}{*}{ Valid } & yes & 6 & 17.1 & 17.6 & 17.6 \\
\hline$=$ NO & & & 18 & 51,4 & 52.9 & 70,6 \\
\hline I OCCASIONALLY & & occasionally & 8 & 22.9 & 23.5 & 94.1 \\
\hline = OTHER & & oiner & 2 & 5.7 & 5.9 & 100.0 \\
\hline \multirow[t]{3}{*}{$=$ SKIPPED } & & Total & 34 & 97.1 & 100,0 & \\
\hline & Missin & & 1 & 2.9 & & \\
\hline & Total & & 35 & 100.0 & & \\
\hline
\end{tabular}

Fig. 3: Results for RQ2 in IBM SPSS

RQ2 interpretation: The research revealed that only 17\% of companies utilize high quality content videos from open sources. Over half of them $(51.4 \%)$ never 
include this option into their in-house training while slightly over a fifth of them occasionally decide to incorporate open source high quality content multimedia into their corporate education. About $8.5 \%$ altogether either did not respond to this question or opted for the "other".

\section{Research question 3 (RQ3) - Chi-square test}

In order to further investigate the relationship between RQ1 and RQ2, the authors formulated research question 3 (RQ3): Is there a link between companies' readiness to use a mix of different educational methods and materials (based on RQ1)and the use of educational videos with quality content from freely available sources (based on RQ2)?

A zero hypothesis (the tested hypothesis) $\mathrm{H} 0$ was formulated as follows: The variables Q1 and Q2 _IND* are independent. An alternative hypothesis H1 was defined as follows: The variables Q1 and Q2 _IND* are dependent. *The variables in Q2 work with categories other than "YES" (e.g. "OCCASIONALLY") merged into "NO". The chi-square test was then run for the detected data. The results can be seen in Chart 3.

\begin{tabular}{|l|r|r|r|}
\hline & Value & df & \multicolumn{1}{|c|}{$\begin{array}{c}\text { Asymptotic } \\
\text { Significance } \\
\text { (2-sided) }\end{array}$} \\
\hline Pearson Chi-Square & $2,729^{\mathrm{a}}$ & 2 &, 256 \\
Likelihood Ratio & 2,956 & 2 &, 228 \\
Linear-by-Linear &, 677 & 1 &, 411 \\
Association & 34 & & \\
N of Valid Cases & & & \\
\hline
\end{tabular}

a. 4 cells $(66.7 \%)$ have expected count less than 5 . The minimum expected count is .71 .

Fig. 4: Results for RQ3 in IBM SPSS

RQ3 interpretation: At the 5\% level of significance we cannot reject the null hypothesis (significance is 0.256 ) which means there has been no link proven between readiness of companies to use a mix of different educational methods and materials and the use of freely accessible educational videos with high quality content.

\section{Pedagogical implications}

The research unveiled that only $40 \%$ of corporate training designers take into account the importance of a rich portfolio of study materials and methods of instruction while designing their courses. It indirectly implies that much more at- 
tention should be given to the popularization of modern teaching methods among the segment of Chief Learning Officers who might not have come across them in their own studies. The same applies to the incorporation of high-quality content videos from open sources as $51.4 \%$ never include this option into their in-house training.

It is clear that ESP teachers in tertiary education exploit a wide portfolio of teaching methods and various multimedia and other technologies; however, the "knowhow" mostly stays within universities. Therefore, the active use of multimedia in tertiary instruction and especially in tertiary learning is of utmost importance for knowledge transfer into practice as it has the potential to positively influence the level of informal learning in general, and corporate courses specifically.

\section{Managerial implications}

As for the infrequent use of high-quality content videos from open sources, it is important to consider the cost of corporate courses' design and development which is usually very high. Sometimes, financial intensity is one of the main reasons why only a limited number of educational courses and learning opportunities are offered to employees. It is important to have in mind that training and development costs should be rather seen as investments of an organization for the future as it undoubtedly affects the innovative performance of employees.

The authors of this article are fully convinced that closer collaboration between university experts and corporations should be established without delay. It should be intensively promoted, financially supported and appreciated by all those concerned with future education of the next generations.

\section{Video in tertiary ESP practice}

The following sub-chapters offer practical information on the implementation of multimedia presentation and video into tertiary ESP practice, namely for the study programme of Marketing Communications.

\subsection{Peer-to-peer multimedia presentations}

Applying the multimedia principles, especially the use of words and graphics rather than words alone, lies in the core of effective multimedia ESP instruction. Recently, it has been in the focus of many research projects. Clark and Mayer in their research write about connections between words and graphics as follows:

According to cognitive theory, generative learning - that is, deeper learning aimed at meaning making - occurs when learners mentally construct connections between words and graphics. This goal is more likely to be achieved with multimedia lessons containing both words and corresponding pictures that 
work together to explain the same to-be-learned content. Adding relevant graphic to words can be a powerful way to help learners engage in active learning. (Clark \& Mayer 2016, p. 76)

Today, apart from static visuals, we can use dynamic graphics, such as motion graphs, animations, or different video formats.

In a classroom setting, within the frame of microlearning, students of ESP classes prepare multimedia presentations while enhancing their knowledge and digital skills. The use of PPTs can foster learning while collaborative learning is required for group presentations, which prepares ground for future workflow learning. Students have to identify, process, and curate appropriate content. Then, they have to select the most valuable information and design their presentations accordingly. Very often, the topics elaborated by students follow the latest trends and complement textbooks used in a course. If teachers help students with rudimentary principles of presentation skills (e.g. signposting language, dealing with question, presenting graphs, etc.), students can master the skills of public speaking step by step. Last but not least, they master digital skills from editing texts and visuals to shooting video clips. In the creative process of incorporating multimedia section into their presentation, they have to master advanced digital skills which will be highly valued by their future employers. Peer-to-peer evaluation, or, perhaps awards for the best presentations, can engage students more and make multimedia learning more memorable and fun.

As for the latest developments of the PowerPoint software itself, Microsoft has implanted virtual reality elements into the latest version of this programme. It is available in Office 365. A new level of automatization and customization was added and these features make it very easy to identify relevant content on the web and create more engaging PPT presentations. Teachers using PPT presentation in their teaching should get familiar with these new functions of PowerPoint so that they can modify their instructions accordingly, making them more specific so that students have to rely more on their own creative competences than the "automatic creativity" offered by the software.

\subsection{A lesson plan with the use of iMovie mobile app}

Shelf-edge Video Strips are emerging in many supermarkets. They represent a new challenge for marketing managers: there is a need to create 4.3" LCD video promotion.

Objective: Let's enhance customer experience directly at the point of sale. 


\section{How to start?}

1. students will work in small teams

2. each team will have at least one tech-savvy student

3. final video projects will be evaluated by peers in a contest for the best project (anonymous voting) which can serve as a motivational factor and enhance students' creativity and engagement

4. students cannot cast their votes for their own project

5. all students will speak English during the whole creative session using the correct terms and phrases

\section{Basic recommendations for a video project}

1. Think of the purpose of your shelf-edge video strip: is it sales promotion, branding or CRM?

2. Chose a product, brand, or company.

3. Write a scenario for your video project.

4. Prepare a storyboard for your project.

5. Create the sense of urgency.

6. Use emotions.

7. Select compelling visuals.

8. Think of interesting and suitable fonts for your marketing message.

9. Combine colours wisely.

10. Create the atmosphere of mutual collaboration.

\section{Task 1 - A video strip}

Equipment needed: phone camera and mobile photo editing applications. Use minimum three photographs in a creative way to highlight: a) product information appeal; b) product benefits; b) emotional appeal; c) buying motives.

If appropriate, use a logo and a claim.

Shoot a 15-second video

a) of your product (e.g. a model dressed in a T-shirt/shirt);

b) of a celebrity representing your brand;

c) on values associated with your brand;

d) of a seasonal offer;

e) of a new product launch;

f) on additional services related to a product (augmented product);

f) on other relevant topics suitable for a shelf-edge video strip.

Task 2 - A text strip

Many mobile apps (e.g. Instagram, iMovie) allow people to add captions to their visuals. If you are not happy with the basic choice and you want to add texts with specific font, size, style, colours and effect, you need some professional tools to help you. These are usually paid apps. Use the in-built features for adding caption in iMovie or other video-editing software. Use your own photographs and the technique of storytelling. Focus on: telling a story, funny dialogues, humorous plots why to buy/not to buy a particular product. Use speech bubbles. 
Task 3 - A masque visuals' strip

Applications needed: Snapchat (or similar)

Use your own photographs and filters in a creative way to highlight buying motives.

\section{Task 4 - A Music strip}

Applications needed: GarageBand, Dictaphone.

You need some incidental music. You can create your own using different options of the GarageBand app, or alternatively check Top 10 Strip Songs of ALL Time! on YouTube and record a part of it using your smartphone (use the Dictaphone app) or use your own tunes/songs. Mind the copyright! Add music to your video strip. You can also buy some reasonably priced ringtones or melodies.

\section{Final remarks}

You can upload your video project to a special folder in Dropbox (or any other cloud solution). Give time to other students to watch the video projects of your colleagues. Invite them to express their opinions and evaluate other video projects.

Organize the contest. Give prizes to the winners!

Inform about the best teams and their video project in the school magazine.

Enjoy your creative session with iMovie!

\section{Discussions and proposals for further research}

The aim of this paper was to examine and critically evaluate the existing opportunities for English teachers to incorporate video formats into their portfolio of teaching methods as well as use them effectively in the process of updating their own teaching materials and lesson plans' design. Based on the literature review and best practice examples from ESP instruction the authors of this paper put forward the pros and cons of the implementation of digital media into ESP instruction for Marketing Communication. An interesting comparison of global trends in video learning used in employee training with the situation in the Czech Republic offers fresh insight into the analysed topic. Though the findings of this research seem to be very promising, we hope that our research will serve as a base for future studies. We propose that further research should be focused on the impact of digital media on technical English courses. Such studies could reveal with precision the overall scores of students who are exposed to digital media and audiovisual materials in ESP instruction with a control group with no access to such materials.

\section{Conclusions}

In the epoch of digital media penetrating both our professional and private lives, it was in the focus of attention of the authors of this treatise to examine and critically evaluate the existing opportunities for English teachers to incorporate video formats into their portfolio of teaching methods as well as use them effectively in the process of updating their own teaching materials.

Based on the literature review of theoretical studies and on primary and secondary research projects, the following findings are to be highlighted: (1) corpo- 
rate $L \& D$ is experiencing a period of rapid transformation thanks to new technologies and communication platforms; (2) universities which try to prepare students well for the daily business practice have to react promptly to the dynamic changes of industries; (3) during the ESP lessons, in their multimedia presentations students demonstrate an array of digital skills, inclusive of the use of open source videos; (4) during the ESP lessons, student can learn how to compile their own video projects with the use of the mobile app iMovie (with the BYOD method); (5) due to the fact that creative ideas for methodological application of video formats are fully transferable into almost any kind of study programmes, the findings of this paper are not limited to ESP only but are applicable elsewhere; (6) the qualitative research revealed that in corporate practice high quality educational videos are used by $17 \%$ of responding companies (always) and in $23 \%$ only occasionally, i.e. more can be done in the field of video learning promotion and content curation of freely accessible materials; (7) the authors of this treatise propose that future research could focus on the impact of digital media on technical English courses to help educators in their work.

In conclusion, it is important not to forget about tertiary teachers and their demanding work. The process of ESP instruction has become rather technological and therefore proper training of university lecturers should be available, IT support reachable and their work should be held in high esteem. They are those who decide today about the character of our society in the years to come.

\section{References}

CLARK, R. C., \& MAYER, R. E. (2016). E-learning and the science of instruction: proven guidelines for consumers and designers of multimedia learning. Fourth edition. Hoboken: Wiley.

JENLINK, P. M., ED. (2019). Multimedia learning theory: preparing for the new generation of students. Lanham, Maryland: Rowman \& Littlefield.

JUKES, I., \& SCHAAF, R. L. (2019). A brief history of the future of education: learning in the age of disruption. Thousand Oaks, California: Corwin.

KniHová, L., \& HRonovÁ, Š. (2015). Motivace ke studiu cizího jazyka a výuka angličtiny pro specifické účely v terciálním vzdělávání. In Evropské pedagogické forum 2015: Přínosy, výzvy a očekávání, 455, 55-64.

MAYER, R. E. (2005) Principles of multimedia learning based on social cues: personalization, voice, and image principles. In MAYER, R. E. (Ed.). The Cambridge Handbook of Multimedia Learning. New York: Cambridge University Press.

Matthews, P. (2013). Informal learning at work: how to boost performance in tough times. Milton Keynes: Three Faces Publishing.

MatThews, P. (2014). Capability at work: how to solve the performance puzzle. Milton Keynes: Three Faces Publishing.

RVVI (2019). Research and development in the Czech Republic. Výzkum a vývoj v ČR [online]. Available at: https://www.vyzkum.cz/Default.aspx?lang=en. 
SARRE, C., \& WhYTE, S. (2017). New Developments in ESP teaching and Learning Reserch. S. I.:

Research-Publishing Net.

SEG RESEARCH (2008). Understanding multimedia learning: Integrating multimedia in the K 12 . Issuu [online]. Available at: https://issuu.com/universidaddavinci/docs/understanding_multimedia_ learning_1.

TrAInINGZone (2019). Research: Which learning technologies are trending in 2019? TrainingZone [online]. Available: https://www.trainingzone.co.uk/resources/

research-which-learning-technologies-are-trending-in-2019.

\section{Authors}

Mgr. Štěpánka Hronová, MBA, Fakulta sociálních studií, Vysoká škola finanční a správní v Praze, e-mail: stepanka.hronova@mail.vsfs.cz

Absolventka ZČU v Plzni oboru Učitelství anglického jazyka a City University of Seattle oboru General Management, účastnice Fulbrightova programu v USA 2000-2001 (výuka anglického jazyka, Downey High School, Downey, Kalifornie). V rámci mobilit vysokoškolských pedagogů Erasmus přednášela na zahraničních partnerských institucích (Belgie, Španělsko), dříve se věnovala též projektové činnosti a výjezdům se středoškolskými studenty na výměnné pobyty (Anglie, Německo, Řecko, Švédsko, Belgie). Věnuje se výuce anglického jazyka a odborných předmětu v angličtině zejména na univerzitách a v korporátní sfére. Zajímá se o progresivní metody výuky jazyka, inovativní učební materiály a digitalizaci ve vzdělávání. $V$ současné době se podílí např. na výuce odborného jazyka v oblasti marketingové komunikace, lektorské činnosti střediska Europe Direct Most a Univerzity třetího věku. Publikuje články a účastní se konferencí týkajících se oblasti EFL/ESP (angličtina jako cizí jazyk a angličtina pro odborné účely), andragogiky, trendu ve vzdělávání dospělých, udržitelnosti a rozvoji lidských zdrojů v korporátní sféře. V současné době je doktorandkou na Vysoké škole ekonomické v Praze a zaměřuje se na oblast udržitelnosti lidských zdrojů ve firmách.

PhDr. Ladislava Knihová, MBA, Fakulta sociálních studií, Vysoká škola finanční a správní v Praze, e-mail: ladislava.knihova@mail.vsfs.cz

Autorka vystudovala lingvistiku na Karlově univerzitě v Praze, specializace angličtin a ruština. Titul PhDr. získala v doktorském studiu tamtéž. V roce 2017 dokončila profesní studium MBA se specializací Marketing \& PR. Více než deset let pracovala v diplomatických službách. V současnosti je zástupcem vedoucího katedry jazyků na VŠFS a pracuje zde jako odborný asistent. Vyučuje angličtinu a odborné marketingové předměty v češtině a angličtině. $V$ posledních letech se několikrát umístila v první desítce předních evropských dodavatelů e-learningových řešení v soutěži Top Ten E-learning Shakers and Movers in Europe. Publikovala řadu odborných článků a pravidelně se účastní řady odborných konferencí v ČR i v zahraničí (Slovensko, UK). Předmětem jejího zájmu je metodologie výuky odborné anglického jazyka, marketingová komunikace, digitální marketing a marketing v sociálních sítích. Specializuje se na výuku angličtiny pro specifické účely (marketing, finance, bankovnictví, management, právo v podnikání, angličtina pro EU, oceňování podniku, účetnictví apod.). Aktuálně studuje doktorský program na Vysoké škole ekonomické v Praze - obor Podniková ekonomika a management se specializací Marketing. 